塑性と加工 60-700, (2019), 136-141.の正誤表

\title{
修正前：
}

$$
\sigma_{b}=p\left(\rho_{m}-t\right)^{2} /\left(2 \rho_{m} t\right)
$$

\section{修正後 :}

$$
\sigma_{b}=p\left(\rho_{m}-t / 2\right)^{2} /\left(2 \rho_{m} t\right)
$$




\title{
論 文
}

外接多角形による降伏関数簡易同定法の数值解析的検証 瀧澤 英男 ${ }^{*}$ 坚玉 渉平**

\section{Numerical Verification of Simplified Identification Method of Yield Function Using Circumscribing Polygon of Yield Locus}

\author{
Hideo TAKIZAWA ${ }^{*}$ and Shohei KODAMA**
}

(Received on June 4, 2018)

\begin{abstract}
A method for identifying the yield function using simple material tests is proposed. The identification accuracy of this method is verified by finite element analysis. In the proposed method, a polygon circumscribing the equal plastic work contour is defined through uniaxial tensile tests, hydraulic bulge test, and plane strain tensile tests. The parameters of the anisotropic yield function are identified as a smooth curve inscribed in the polygon. The virtual material tests of three material models, namely, mild steel, aluminium alloy, and pure titanium, are conducted by the finite element method. On the basis of the results, stress measurement error and yield surface identification error are discussed. When the material exhibits strong in-plane anisotropy, the measurement error of equi-biaxial stress in the hydraulic bulge test becomes large. When the initial gradient of work hardening is large, the stress value of the circumscribed line of the small plastic strain stage in the plane strain tensile test is estimated to be lower than that on the true yield surface. These errors affect the identification accuracy of the material parameters of the yield function quantitatively, but the difference between the identified locus and true yield locus is small. The proposed method is feasible as a simple identification method of the yield function.
\end{abstract}

Key words: sheet metal forming, material testing, anisotropy, yield function, biaxial tensile test, finite element method, verification, material parameter identification.

\section{1. 緒 言}

塑性加工プロセス設計の効率化のために有限要素解析が 広く用いられている. 解析精度の向上のためには，材料モ デルの精度向上が不可欠であり，特に圧延板を素材とする 板成形解析においては，異方性降伏関数を用いた材料モデ ルの必要性が広く認識されている ${ }^{1)}$.

材料の塑性モデルの異方性を表現する異方性降伏関数は, 現在までに数多く提案されている 2),3). 近年提案された降 伏関数は, 数式の複雑化と材料定数の増加により, その表 現力は飛躍的に向上している。これらの降伏関数のいくつ かは市販有限要素解析ソフトウェアにも組み込まれてお $り^{3)}$, 実務的な工程設計でも利用できる環境が整いつつある.

異方性降伏関数の材料パラメータを求めるためには，単 軸引張試験だけでは不十分であり，二軸応力場での材料試 験を必要とする．任意の応力比を付与できる材料試験につ いては，十字形試験片を用いる二軸応力試験 4)およ゙円管

\footnotetext{
*日本工業大学 基幹工学部 機械工学科 $\bar{\top} 345-8501$ 埼玉県南埼玉郡 宮代町学園台 4-1

Department of Mechanical Engineering, Nippon Institute of Technology, 4-1 Gakuendai, Miyashiro-machi, Saitama 345-8501, Japan. E-mail:htaki@nit.ac.jp

** 日本工業大学 大学院 工学研究科 機械システム工学専攻 同上 Graduate School of Engineering, Nippon Institute of Technology, ibid.
}

に加工した試験片を用いる軸力内圧型二軸応力試験 5)が提 案されている. 前者の試験法は国際標準規格 (ISO) に登 録され ${ }^{6)}$, 市販の専用試験機が開発される 7)など，学術研 究から産業利用へと移行しつつある.

しかしながら, 二軸応力試験にもとづく異方性降伏関数 の産業利用は，現在，十分に普及しているとは言い難い。 普及の障壁は，特殊な試験設備への投資に対するシミュレ ーション高度化の効果が定量化しにくいことにある．この 課題に対する当面の対策として，任意の応力比は与えられ なくとも，廉価な材料試験により材料パラメータを同定で きる方法 ${ }^{8) 10)}$ が求められる.

本研究では, 基準となる「単軸引張試験」に加え, 古典 的試験法である「液圧バルジ試験」および引張試験機で実 施可能な「平面ひずみ引張試験」の計三種の材料試験法を 用いる。これらの試験結果から降伏曲面の外接多角形を定 義して, 異方性降伏関数を同定する. 各材料試験の有限要 素解析を仮想実験とみなし, 材料試験における応力の測定 誤差および降伏関数の同定精度を定量的に評価する.

\section{2. 降伏関数同定手法および数值解析的検証法}

\section{1 外接多角形による降伏曲面の概略形状の測定}

本研究では, 材料モデル同定法の基礎検討として, 測定 
対象とする塑性構成式に以下の前提を置く.

(1) 加工硬化特性に等方硬化を仮定し, 等塑性仕事面と 降伏曲面を同一視する ${ }^{11)}$.

(2) 塑性ひずみ増分方向は，関連流れ則を満たす ${ }^{12) .}$

(3) 圧延方向（RD）と圧延直交方向（TD）を主軸とする 直交異方性を仮定する.

これらの前提のもとで，以下に示す三種の材料試験により 降伏曲面の外接多角形を測定する. Fig. 1 に本研究で提案 する降伏曲面同定法の模式説明図を示す.

(1) 単軸引張試験 : 通常の単軸引張試験を行い, ここか ら加工硬化曲線および Lankford の $r$ 值を求める.これによ り，応力空間における応力軸と降伏曲面の交点およびこの 点における降伏曲面の法線方向が定まる.

(2) 等二軸応力試験 : 円形ダイスを用いる液圧バルジ試 験により頭頂部に等二軸応力を与える。また，頭頂部にひ ずみゲージを貼付し, 異方性主軸方向の塑性ひずみ増分比 $r_{b}=d \varepsilon_{y}^{p} / d \varepsilon_{x}^{p}$ を求める. これにより, 応力空間における等 二軸降伏応力とこの点における降伏曲面の法線方向が求ま る.

(3) 平面ひずみ引張試験 : 幅広の試験片を近接したチャ ックで引張ることで，試験片幅方向のひずみがゼロとなる 変形状態を与える. 弾性変形を微小として全ひずみ増分で

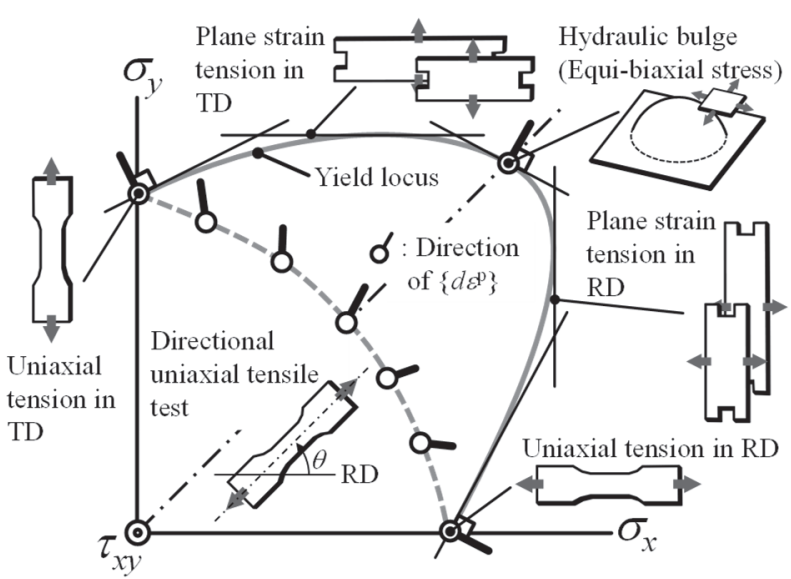

Fig. 1 Circumscribing polygon of yield locus measured by 3 types of simple material tests

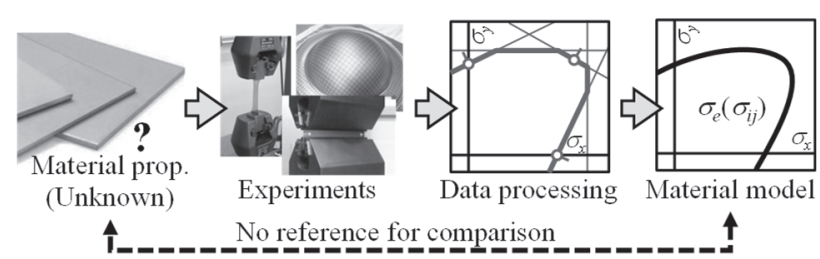

(a) Experimental procedure to determine material model

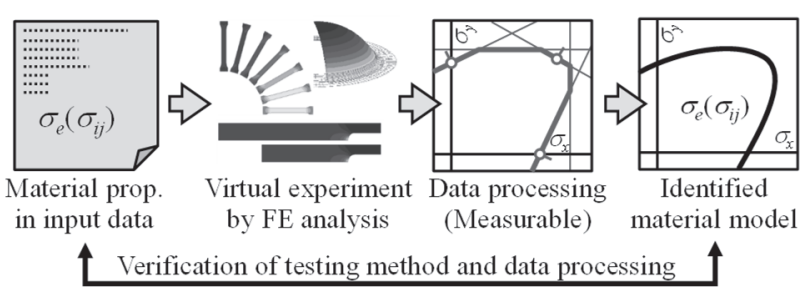

(b) Verification of methodology for material modeling

Fig. 2 Numerical verification of material testing method and identification procedure to determine yield functions
塑性ひずみ増分を近似し，降伏曲面の法線が引張り方向を 向く応力点の最大主応力, つまり, 異方性主軸方向への降 伏曲面の張出し量を決定する.

以上の材料試験により，Fig. 1 に示すような降伏曲面の 外接多角形が定義できる. 本同定法では，三つの応力点を 通り，この多角形に内接する滑らかな曲線として降伏曲面 の形状を同定する.

\section{2 数値解析による検証}

Fig. 2 に数值解析を用いた材料モデル同定法の検証の枠 組みを示す，材料モデル同定法の妥当性を実験的に検証す ることは難しい。 ある材料試験法で実験的に材料特性を測 定し，バラツキの小さな結果が得られたとしても，同定し たモデルが正解であることを証明することはできない。こ れは正解が既知の材料モデルを持った材料が明確には存在 しないためである。一方，有限要素解析では，材料モデル の正解は入力データとして明示的に与えられる。つまり， 同定すべき材料モデルの正解の存在を前提として, 材料モ デル同定法を検証することができる.

本報告では，材料試験の有限要素解析を仮想実験とみな し ${ }^{13), 14)}$ ，材料モデル同定法の妥当性を検証する．上述した 一連の材料試験を数值解析し, この仮想材料試験の解析結 果のうち実験的に測定可能な物理量（例えばロードセルに よって測定される引張荷重，ひずみゲージによる局所ひず みの測定值など）のみを利用して，材料モデルの同定を行 う. 同定された材料モデルと解析の入力として与えた正解 の材料モデルを比較することで，材料モデル同定のための 材料試験法および一連のデータ処理方法の妥当性を検証す る.

当然, 数值解析では生じない様々な測定誤差が実験では 生じる。しかし，外乱的な誤差を含まない数值解析的検証 で十分な同定精度が得られなければ，材料モデル同定法と して本質的に不適切と判断できる。つまり，本検証は，材 料モデル同定法の「必要条件の検証」と位置付けられる.

\section{3. 材料試験の有限要素解析}

\section{1 仮想材料試験の供試材}

同定対象として想定した三種類の材料の特性を Table 1

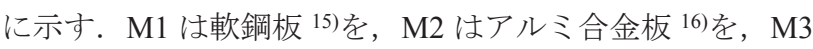

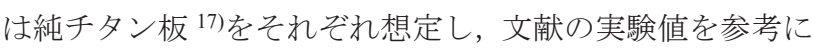
材料パラメータを設定した。降伏関数には Yld2000-2d ${ }^{18)}$ 用いた．Fig. 3 に想定材料の加工硬化曲線（RD 方向の単軸 引張における応力ひずみ曲線), 異方性主軸を主応力とした ときの降伏曲線および $r$ 值の面内分布を示寸. M1 材およ び M3 材は面内の塑性異方性が強く, M3 材は降伏初期で の加工硬化勾配が大きい. 弾性特性には等方性を仮定した.

\section{2 仮想材料試験の条件および真応力の算出方法}

Fig. 4 に各試験の試験片形状および境界条件を示す. 板 材の RD および TD を $x$ 方向および $y$ 方向とする. 試験片 の初期板厚 $t_{0}$ は $1 \mathrm{~mm}$ と設定した。 以下, 各試験の試験条 件および真応力一真ひずみ曲線の算出方法を示す.

(1) 単軸引張試験 単軸引張試験片は, JIS Z 2241 の 13B 号形状とした。試験片中心に二軸ひずみゲージを貼付する ことを想定し，この位置での局所ひずみを仮想測定值とし て用いる. 引張方向および幅方向の真ひずみをそれぞれ $\varepsilon_{l}$ 
Table 1 Material parameters as input for simulations of virtual material tests

\begin{tabular}{l|l|l|c|c|c|c|c|c|c|c|c|c|c|c|c}
\hline \multicolumn{2}{c|}{ Material } & \multicolumn{1}{|c|}{ Elastic prop. } & \multicolumn{3}{c|}{ Flow stress : $C\left(\bar{\varepsilon}^{p}+\varepsilon_{0}\right)^{n}$} & \multicolumn{1}{c}{ Material parameters in Yld2000-2d } \\
\hline Code & Assumed & $E / \mathrm{GPa}$ & $v$ & $C / \mathrm{MPa}$ & $\varepsilon_{0}$ & $n$ & $\alpha_{1}$ & $\alpha_{2}$ & $\alpha_{3}$ & $\alpha_{4}$ & $\alpha_{5}$ & $\alpha_{6}$ & $\alpha_{7}$ & $\alpha_{8}$ & $M$ \\
\hline M1 & SPCE & 200 & 0.3 & 564.0 & $5.90 \cdot 10^{-3}$ & 0.275 & 0.939 & 1.184 & 0.887 & 0.877 & 0.933 & 0.802 & 1.046 & 1.023 & 5.90 \\
\hline M2 & A5182-O & 70.0 & 0.3 & 716.7 & $1.55 \cdot 10^{-2}$ & 0.421 & 0.966 & 1.000 & 0.892 & 1.010 & 0.994 & 0.916 & 0.984 & 1.157 & 8.86 \\
\hline M3 & Pure Ti & 100 & 0.3 & 455.7 & $1.34 \cdot 10^{-4}$ & 0.162 & 0.976 & 1.001 & 0.888 & 0.786 & 0.853 & 0.369 & 0.973 & 0.852 & 6.13 \\
\hline
\end{tabular}

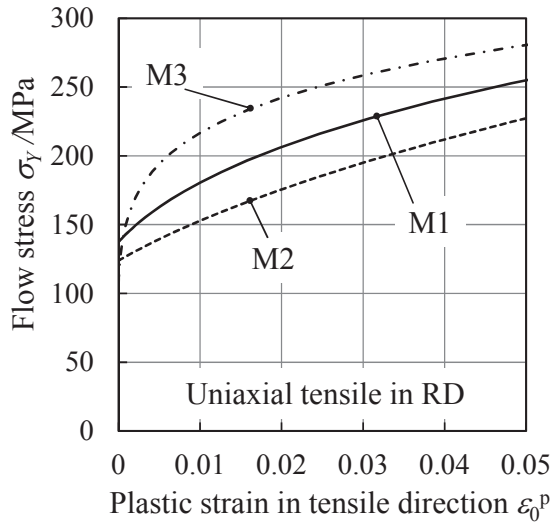

(a) Work hardening curves in RD tensile tests

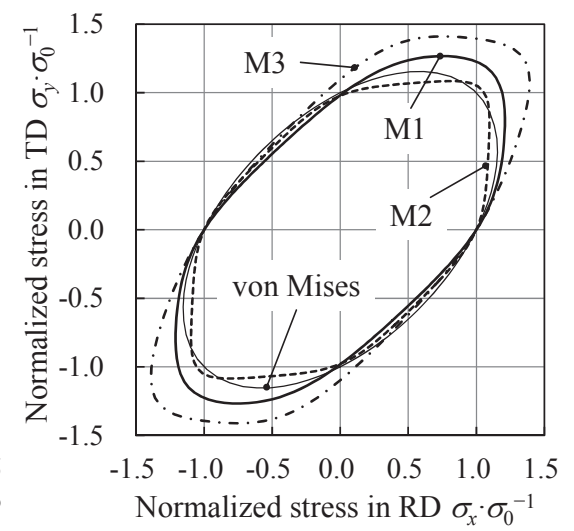

(b) Yield loci in normalized $\sigma_{x}-\sigma_{y}$ plane

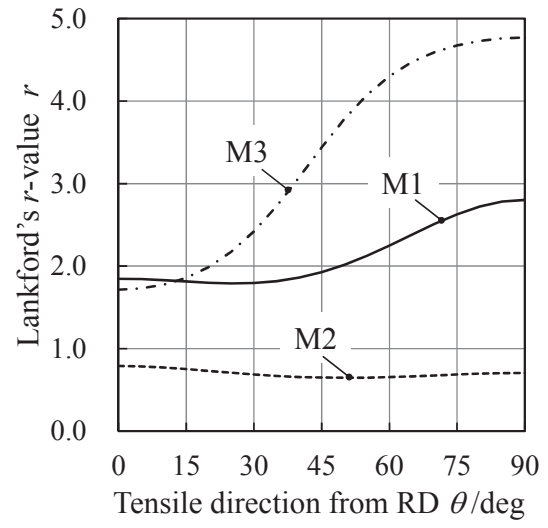

(c) $r$-value in directional tensile tests

Fig. 3 Material properties used in simulations of virtual material tests

および $\varepsilon_{w}$ とし, 体積一定条件を仮定して, 以下の式で引張 方向の真応力および $r$ 值を求める.

$$
\sigma_{\theta}=\frac{F \exp \left(\varepsilon_{l}\right)}{t_{0} w_{0}}, \quad r_{\theta}=-\frac{d \varepsilon_{w}}{d \varepsilon_{l}+d \varepsilon_{w}}
$$

ここで $\theta$ はD に対する引張方向の角度を示す.

(2) 平面ひずみ引張試験 平面ひずみ引張試験については 様々な試験片形状が提案されているが 19),20), 正確な測定の ために, 差分荷重による補正を用いた平面ひずみ引張試 験 21)を行う。この試験法では, 試験片切欠き部周辺に生じ るひずみ場の乱れに起因する測定精度低下を回避するため に，切欠き部形状が同一で幅の異なる二種の試験片を用い て平面ひずみ領域の応力を求める. 幅広および幅狭の試験 片をそれぞれ $w$ および $n$ で示す. 切欠き部周辺でのひずみ 場の乱れが両試験片で同一であれば，引張荷重 $F$ および試 験片幅 $W$ 差分により, 切欠き部の荷重への影響を除去す ることができる. 試験片 $w$ および $n$ の試験荷重を $F_{w}$ およ び $F_{n}$, 試験片幅を $W_{w}$ および $W_{n}$, 引張方向の真ひずみを $\varepsilon_{l}$ として, 以下の式で平面ひずみ状態の引張応力 $\sigma_{l}$ を求める.

$$
\sigma_{l}=\frac{\left(F_{w}-F_{n}\right) \exp \left(\varepsilon_{l}\right)}{\left(W_{w}-W_{n}\right) t_{0}}
$$

なお，この試験では幅方向応力 $\sigma_{w}$ は実験的には求まらな い. しかし, 幅方向の塑性ひず夕増分 $d \varepsilon_{w}^{p}$ をゼロと近似す るため, $\sigma_{w}$ の不明は塑性仕事の算出を妨げない.

(3) 等二軸応力試験 等二軸応力試験として液圧バルジ試 験を行う. ダイス孔径を $150 \mathrm{~mm}$ とし, 曲率計の全幅を $20 \mathrm{~mm}$ とする ${ }^{14)}$.

バルジ頭頂部外表面に貼付したひずみゲージで測定され る二軸ひずみを $\varepsilon_{s 1}, \varepsilon_{s 2}$ とする. 外表面の三点から求まる 曲率半径を $\rho_{s}$, 変形後板厚を $t$ とする. 板厚が十分薄いと すれば, Bernoulli-Euler の仮定により，板厚中心の面内方 向ひずみ $\varepsilon_{m 1}, \varepsilon_{m 2}$ と板厚 $t$ には以下の関係式が成立する.

$$
\begin{aligned}
& t=t_{0} \exp \left(-\varepsilon_{m 1}-\varepsilon_{m 2}\right) \\
& \rho_{m}=\rho_{s}-t / 2 \\
& \varepsilon_{m 1}=\varepsilon_{s 1}-t /\left(2 \rho_{m}\right) \\
& \varepsilon_{m 2}=\varepsilon_{s 2}-t /\left(2 \rho_{m}\right)
\end{aligned}
$$

ここで, 下付添字 $m$ は板厚中央での值を示し, 体積一定条 件を用いている。 これらの式より $\varepsilon_{m 1}, \varepsilon_{m 2}, \rho_{m}$ および $t$

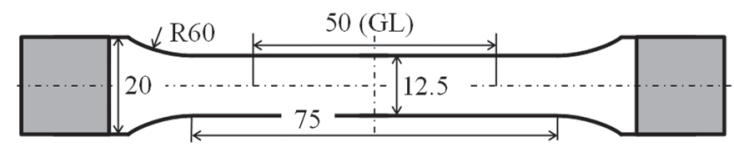

(a) Test piece for uniaxial tensile test (JS 13B)

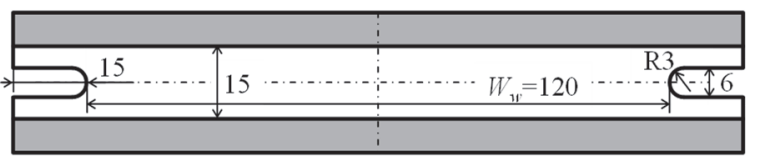

(b1) Wide test piece for plane strain tensile test

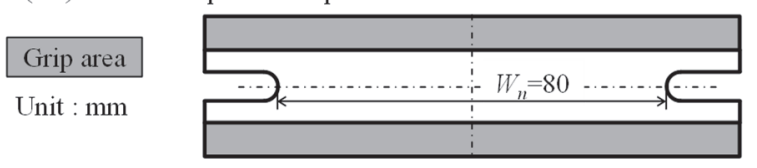

(b2) Narrow test piece for plane strain tensile test

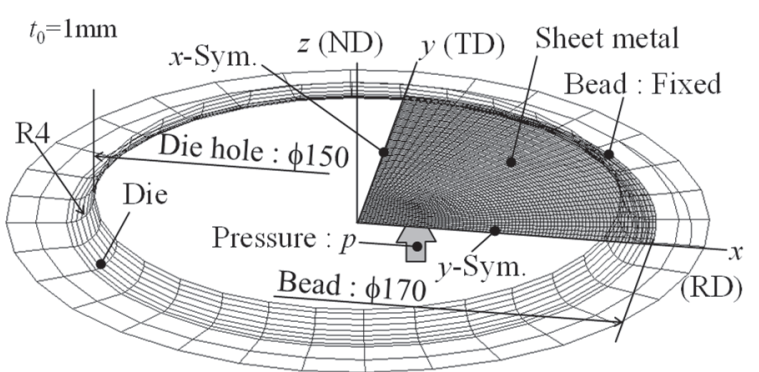

(c) Geometry and boundary conditions for hydraulic bulge test

Fig. 4 Dimensions and boundary conditions for 3 types of simple tests 


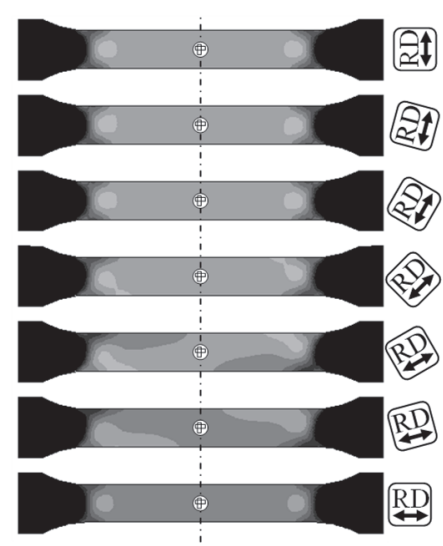

(a) Uniaxial tensile test

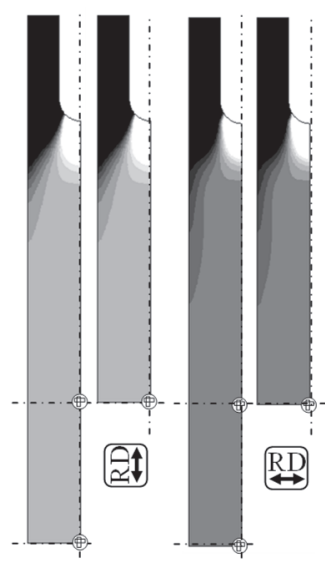

(b) Plane strain tensile test

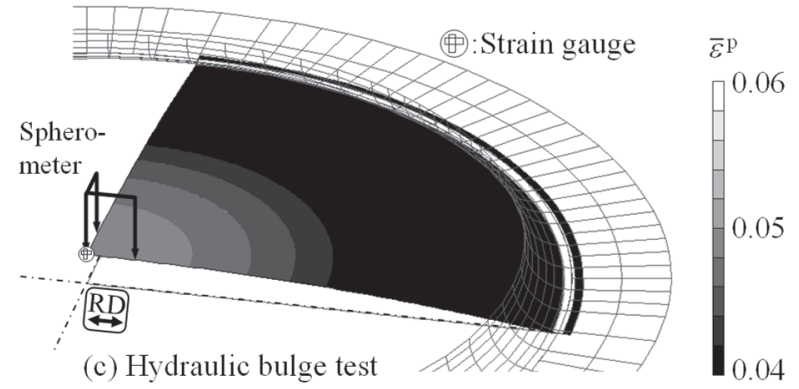

Fig. 5 Simulation of 3 types of simple tests (M3)

を非線形方程式の解として求める. 内圧を $p$ として, 以下 の応力算出式により等二軸応力 $\sigma_{b}$ を求める ${ }^{14)}$.

$$
\sigma_{b}=p\left(\rho_{m}-t\right)^{2} /\left(2 \rho_{m} t\right)
$$

\section{3 有限要素解析}

単軸引張試験および平面ひずみ引張試験の解析は, 平面 応力問題として二次元解析を行う. せん断応力 $\tau_{x y}$ の影響 を測定するために単軸引張試験は RD から TD まで $15 \mathrm{deg}$ 毎の計 7 方向に対して, 平面ひずみ引張試験は RD と TD の 2 方向に対してそれぞれ行う. 液圧バルジ試験の解析に は面外せん断成分を考慮しない薄肉シェル要素を用いて $1 / 4$ 領域をモデル化する. なお, シェル要素の板厚方向の 積分点は 11 点とする.
一例として, Fig. 5 に M3 材の一連の材料試験の解析結 果を示す。図はひずみ測定位置の相当塑性ひずみ $\bar{\varepsilon}^{p}$ が約 0.05 の時の $\bar{\varepsilon}^{p}$ の分布を示している.

\section{4. 降伏関数の同定手法の検証}

\section{1 応力の測定值と真値の比較}

降伏関数同定の前に，仮想材料試験における応力の測定 精度を検証する. Fig. 6 に仮想実験の可計測值から求めた 応力（仮想測定值）と，ひずみゲージの貼付想定位置にお ける有限要素内の積分点で算出された応力（真值）との比 較を示す．横軸は各試験の応力成分に対応する真ひずみを 示す.

単軸引張試験および平面ひずみ引張試験の仮想測定值は 真值とほぼ一致している。これに対して液圧バルジ試験で は, 面内異方性の強い M1 材および M3 材で, 仮想測定值 が真值から乘離している. 異方性の強い板材の等二軸応力 状態を液圧バルジ試験で正確に実現する難しさについては, 吉田が既に指摘しており ${ }^{14)}$ ，本結果はこれと一致する.

なお，単軸引張試験において異方性主軸と引張方向が一 致しない場合は，付加的なせん断応力が発生するが，本条 件でのせん断応力は, 引張応力の $0.2 \%$ 程度であったため無 視した。

\section{2 等塑性仕事面の外接多角形の評価}

等塑性仕事面の外接多角形を算出するために，仮想実験 により測定された応力と塑性ひずみを用いて, 単位体積あ たりの塑性仕事を求める。ここでは，等塑性仕事面を以下 のように表現する．RD の単軸引張試験において引張方向

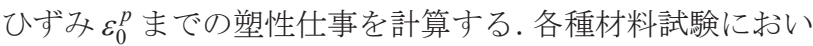
$\tau \varepsilon_{0}^{p}$ に対応する塑性仕事と等しい塑性仕事がなされた時 の応力を求め, この応力を用いて等塑性仕事面の外接多角 形を定める. 等塑性仕事のレベルは基準塑性ひずみ $\varepsilon_{0}^{p}$ で代 表して表す ${ }^{22)}$.

Fig. 7 に仮想測定值から求めた等塑性仕事面の外接多角 形を, 解析の入力として与えた正解の降伏曲面と共に示す. 低ひずみ $\left(\varepsilon_{0}^{p}=0.002\right)$ では，いずれの材料でも平面ひずみ 引張試験で測定される外接線が正解の降伏曲面の内側に位 置している. この傾向は初期降伏直後の加工硬化勾配が大
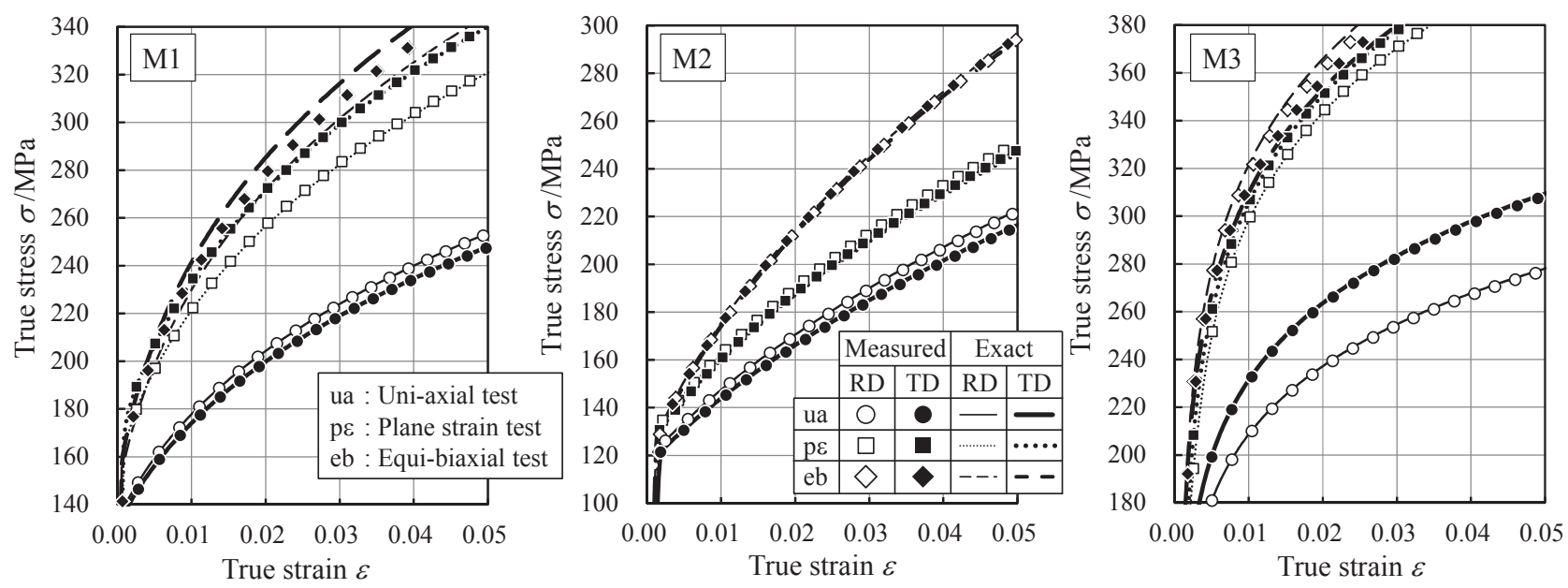

Fig. 6 Accuracy of stress measurement by 3 types of simple test (Measured: Calculated from measurable values in virtual experiments, Exact: Local values at integration point in element) 

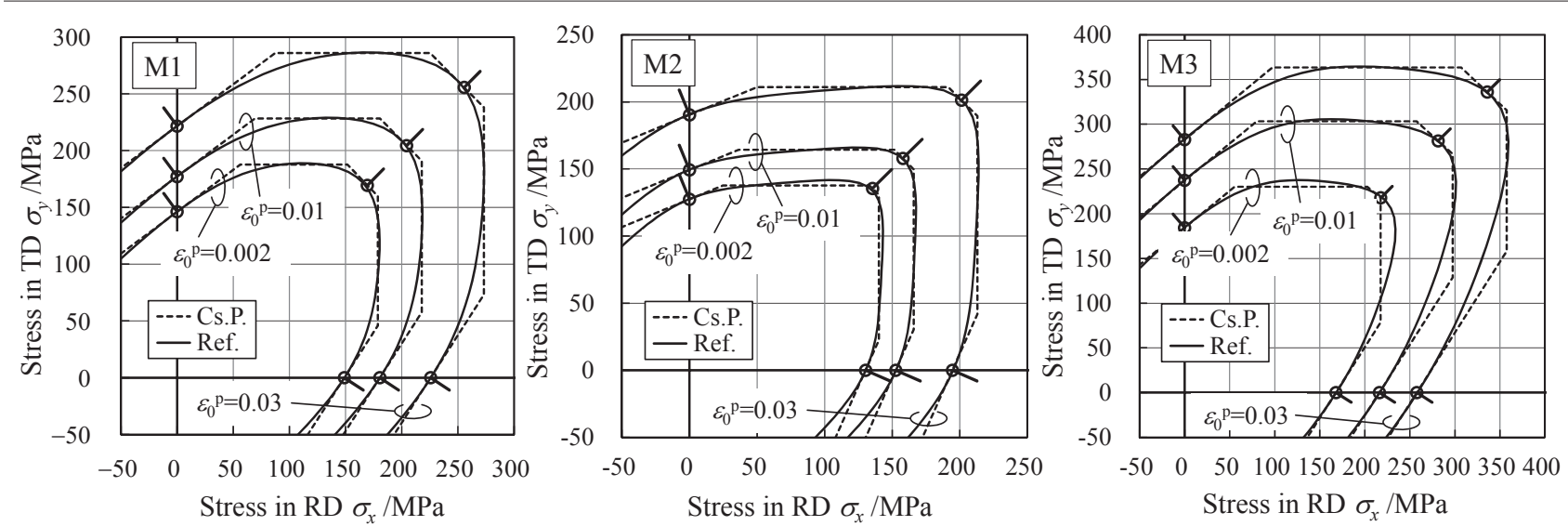

Fig. 7 Circumscribing polygon (Cs.P.) of equal plastic work calculated from virtual experiments and reference yield loci

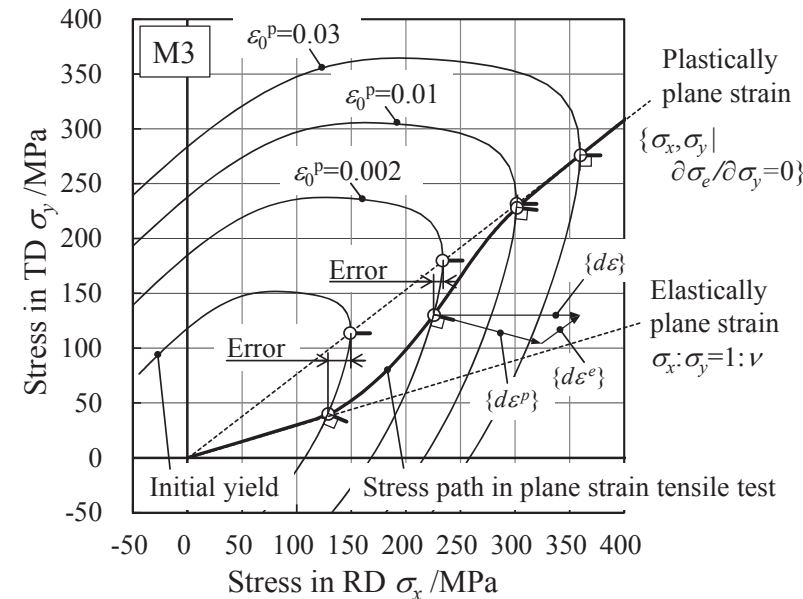

Fig. 8 Illustration for stress evaluation error of plane strain tensile test in small plastic strain stage

\section{きい M3 材で顕著である.}

この理由を Fig. 8 を用いて説明する．平面ひずみ状態の 応力比は, 弹性状態では Poisson 比によって決まる. しか し, 降伏直後に応力経路が変化し, 塑性変形の発達に伴い, 降伏曲面上で平面ひずみ状態を法線とする応力比 $\left(\sigma_{e}\right.$ を降 伏関数として $\partial \sigma_{e} / \partial \sigma_{y}=0$ を満た寸応力比）に漸近してい く，加工硬化勾配が大きいほど，また降伏曲面における平 面ひずみ状態の応力比が等二軸に近いほど, この遷移領域 の影響は大きくなる。遷移領域における平面ひずみ外接線 は，同定すべき降伏曲面の平面ひず夕状態を正確に表現で きないため, 平面ひずみ引張状態の応力值が低く算出され る.ただし，塑性ひずみの増加により，この誤差は軽微と なり, $\varepsilon_{0}^{p}=0.03$ で測定された平面ひずみ外接線は, 正解の

Table 2 Identified material parameters and the error relative to reference $\left(\varepsilon_{0}^{p}=0.05\right)$

\begin{tabular}{c|c|c|c|c|c|c|c|c|c}
\hline \multirow{2}{*}{$\begin{array}{c}\text { Mate } \\
\text { rial }\end{array}$} & \multicolumn{6}{|c|}{ Identified material parameters in Yld2000-2d (\% error to reference) } \\
\cline { 2 - 10 } & $\alpha_{1}$ & $\alpha_{2}$ & $\alpha_{3}$ & $\alpha_{4}$ & $\alpha_{5}$ & $\alpha_{6}$ & $\alpha_{7}$ & $\alpha_{8}$ & $M$ \\
\hline \multirow{2}{*}{ M1 } & 0.923 & 1.194 & 0.959 & 0.885 & 0.921 & 0.724 & 1.046 & 1.028 & 5.928 \\
\cline { 2 - 11 } & $-1.74 \%$ & $0.81 \%$ & $8.12 \%$ & $0.87 \%$ & $-1.33 \%$ & $-9.71 \%$ & $0.04 \%$ & $0.53 \%$ & $0.47 \%$ \\
\hline \multirow{2}{*}{ M2 } & 0.970 & 0.996 & 0.876 & 1.006 & 0.994 & 0.923 & 0.984 & 1.157 & 9.093 \\
\cline { 2 - 10 } & $0.38 \%$ & $-0.40 \%$ & $-1.81 \%$ & $-0.39 \%$ & $0.05 \%$ & $0.75 \%$ & $0.03 \%$ & $0.01 \%$ & $2.63 \%$ \\
\hline \multirow{2}{*}{ M3 } & 0.993 & 0.992 & 0.849 & 0.784 & 0.859 & 0.414 & 0.971 & 0.849 & 6.138 \\
\cline { 2 - 9 } & $1.73 \%$ & $-0.90 \%$ & $-4.35 \%$ & $-0.25 \%$ & $0.69 \%$ & $12.27 \%$ & $-0.15 \%$ & $-0.38 \%$ & $0.13 \%$ \\
\hline
\end{tabular}

: $\mid$ error $\mid>1 \%$
降伏曲面にほぼ接している.

\section{3 同定した降伏関数の評価}

前節で示した等塑性仕事面の外接多角形から，降伏関数 を同定する．降伏関数の材料パラメータは，以下の条件を 満たすように決定する。(1)単軸および等二軸引張試験で求 めた応力点を通る。(2)単軸引張りにおける $r$ 值または等二 軸応力における $r_{b}$ から求まる塑性ひずみ増分方向を降伏曲 面の外向き法線とする. (3)降伏曲面の異方性主軸方向の最 大応力は平面ひずみ引張りの応力值と一致する。

本研究で想定した材料試験は, 7 方向の単軸引張試験, 2 方向の平面ひずみ引張試験および等二軸応力試験であり, 応力值について 10 条件, 塑性ひずみ増分方向について 8 条件の合計 18 条件となる。これより最大 18 パラメータを 含む降伏関数を同定できる可能性がある。今回用いる降伏 関数 Yld2000-2d の材料パラメータは, 次数 $M$ を加えても 9 個であるため，以下に示す誤差の自乗和の平方根を目的関

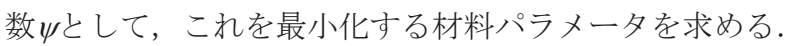

$$
\begin{gathered}
\psi=\frac{w_{\sigma}}{\sigma_{0}} \sqrt{\begin{array}{c}
\sum_{i=0}^{6}\left(\sigma_{15 i}^{\mathrm{ua}}-\tilde{\sigma}_{15 i}^{\mathrm{ua}}\right)^{2}+\sum_{i=0}^{1}\left(\sigma_{90 i}^{\mathrm{p} \varepsilon}-\tilde{\sigma}_{90 i}^{\mathrm{p} \varepsilon}\right)^{2} \\
+\left(\sigma_{b}^{\mathrm{eb}}-\tilde{\sigma}_{b}^{\mathrm{eb}}\right)^{2}
\end{array}} \\
+w_{\beta} \sqrt{\sum_{i=0}^{6}\left(\beta_{15 i}^{\mathrm{ua}}-\tilde{\beta}_{15 i}^{\mathrm{ua}}\right)^{2}+\left(\beta^{\mathrm{eb}}-\tilde{\beta}^{\mathrm{eb}}\right)^{2}}
\end{gathered}
$$

ここで，右上添字の ua, p\&および eb は，それぞれ単軸， 平面ひず夕および等二軸の各試験での值を示す。 $\sigma$ は応力 值を， $\beta$ は降伏曲面の法線方向の角度を $\mathrm{rad}$ 単位で表した 值である. 波線（）付きの変数は同定モデルの值を，波 線無しの值は測定された外接多角形の值を示す. $w_{\sigma}$ と $w_{\beta}$ は応力と法線方向の誤差に対する重みであり，今 回は $w_{\sigma} / w_{\beta}=2$ を用いた。 この場合, $\beta$ の $1 \mathrm{deg}$ の 誤差が応力の $1 \%$ の誤差とほぼ等価に扱われるこ とを意味している。誤差最小化計算は, Microsoft 社の表計算ソフト Excel に標準搭載されている Solver 機能で十分である.

Table 2 に同定した降伏関数のパラメータの一 覧を示す. 表の各行の下段には Table 1 に示した 正解に対する相対誤差を示す，面内異方性の強い M1 および M3 材では，パラメータとしては，4.1 で述べた等二軸試験の応力測定誤差に起因する 同定誤差が約 10\%生じている. 

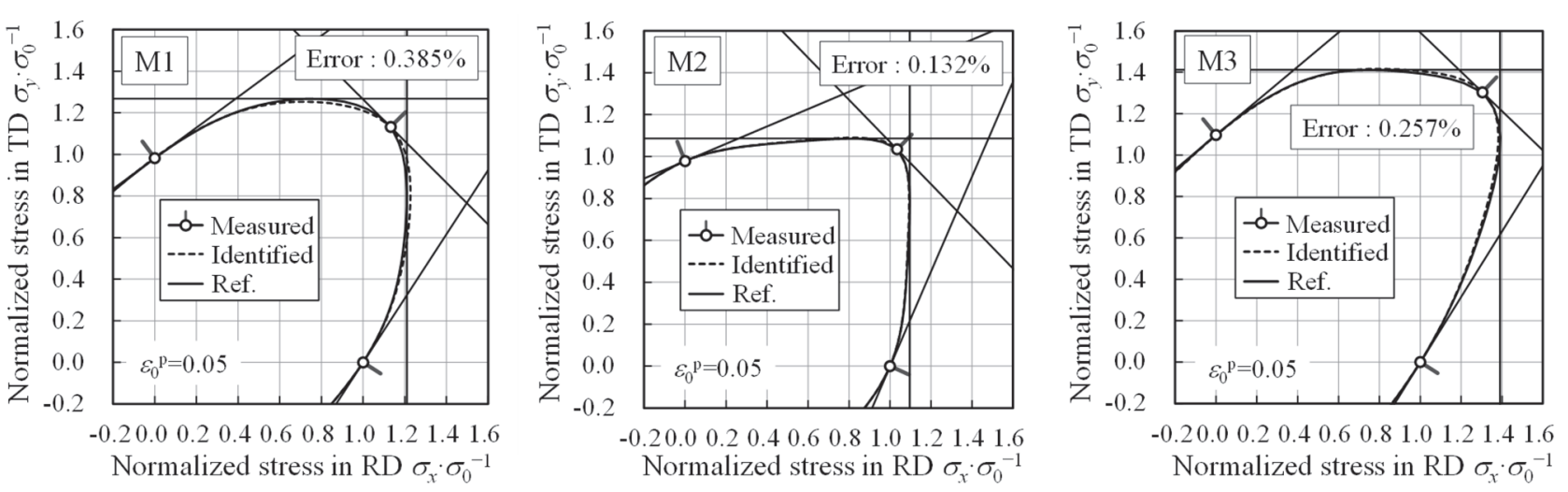

Fig. 9 Identified yield loci reproduced using circumscribing polygon and reference yield loci

Fig. 9 に $\varepsilon_{0}^{p}=0.05$ において同定した降伏曲線を正解の曲 線とともに示す。いずれの材料でも同定した降伏曲面は仮 想材料試験で求めた外接多角形にほぼ内接している。正解 の降伏曲面と比較すると, 等二軸状態での応力測定精度に 課題があるため, M1 および M3 材では, 等二軸近傍での 降伏曲線の再現精度がわずかに低い, しかし, 同定した降 伏曲面の応力空間での同定誤差は正解に対して $0.4 \%$ 以下 であり，正解とほぼ同一の形状を再現できている.

Table 2 に示した材料パラメータの数值上の比較で見ら れた大きな誤差は, Fig. 9 では見られず, 外接多角形を用 いた同定法で降伏曲面の形状を補足できている.

\section{5. 結 言}

単軸引張試験, 液圧バルジによる等二軸応力試験および 差分荷重を用いた平面ひずみ引張試験を用いて，等塑性仕 事面に外接する多角形を求め, これに内接する滑らかな曲 線として異方性降伏関数を同定する手法を示した。また， 軟鋼，アルミ合金および純チタンを想定した仮想実験を行 い, 応力測定誤差および降伏曲面同定誤差について検討し た. 以下に得られた知見をまとめる.

(1) 液圧バルジ試験による等二軸応力の測定誤差は, 面内 異方性の強い板材で大きくなる，また，平面ひずみ引張 試験では, 加工硬化の初期勾配が大きい材料で，低ひず み域の外接線の応力值を低く見積もる傾向がある.

(2) これらの誤差は降伏関数の材料パラメータの同定精度 に影響を与えるが, 基準塑性ひずみ 0.05 における降伏曲 面の同定誤差は軽微であった。

本研究を進めるにあたって東京農工大学 桑原利彦教授 に多くの示唆を頂いた。また, 本研究は (一社) 軽金属学 会の「高精度板成形シミュレーションの普及化検討研究部 会」および (一社) 日本鉄鋼協会の「先進的多軸応力試験 による鋼板成形の高度化研究会」の活動の一部として実施 した。ここに謝意を表する.

\section{参 考 文 献}

1) Kuwabara, T. : Int. J. Plast., 23-3 (2007), 385-419.

2) Banabic, D., Barlat, F., Cazacu, O. \& Kuwabara, T. : Int. J. Mater. Form., 3 (2010), 165-189.

3) Banabic, D. : Sheet Metal Forming Processes -Constitutive Modelling and Numerical Simulation-, (2010), 30-120, Springer.
4) Kuwabara, T. \& Ikeda, S. : J. Jpn. Soc. Technol. Plast., 40-457 (1999), 145-149.

5) Kuwabara, T., Narihara, K., Yoshida, K. \& Takahashi, S. : J. Jpn. Soc. Technol. Plast., 44-506 (2003), 281-286.

6) ISO $16842: 2014$ Metallic materials Sheet and strip Biaxial tensile testing method using a cruciform test piece.

7) Matsumoto, S., Tashiro, K., Mazaki, A., Ikeda, S., Yoshida, K., Takahashi, S. \& Kuwabara, T. : J. Jpn. Soc. Technol. Plast., 53-623 (2012), 1065-1069.

8) Aretz, H., Hopperstad, O.S. \& Lademo, O.-G. : J. Mater. Process. Technol., 186 (2007), 221-235.

9) Murayama, Y., Obara, K. \& Ikeda, K. : J. Jpn. Soc. Technol. Plast., 35-399 (1994), 349-354.

10) Aydın, M.-S., Gerlacha, J., Kesslera, L. \& Tekkaya, A.E. : J. Mater. Process. Technol., 211 (2011), 1957-1964.

11) Hill, R., Hecker, S. S. \& Stout, M. G. : Int. J. Solids Struct., 31 (1994), 2999-3021.

12) Drucker, D.C. : Proc. 1st US Nat. Congr. Appl. Mech., (1951), 411-418.

13) Hanabusa, Y., Takizawa, H. \& Kuwabara, T. : J. Mater. Process. Technol., 213 (2013), 961-970.

14) Yoshida, K.: ISIJ Int., 52-1 (2013), 86-95.

15) Nakano, H., Hakoyama, T. \& Kuwabara, T. : The 20th ESAFORM, AIP Conf. Proc., 1896 (2017), 020014.

16) Kawaguchi, J., Kuwabara, T. \& Sakurai, T. : J. Jpn. Inst. Light Met., 65-11 (2015), 554-560.

17) Ishiki, M., Kuwabara, T., Yamaguchi, M., Maeda, K., Hayashida, Y. \& Itsumi, Y. : Trans. Jpn. Soc. Mech. Eng. A, 75-752 (2009), 491-500.

18) Barlat, F., Brem, J.C., Yoon, J.W., Chung, K., Dick, R.E., Lege, D.J., Pourboghrat, F., Choi, S.H. \& Chu, E. : Int. J. Plast., 19 (2003), 1297-1319.

19) Wagoner, R.H. \& Laukonis, J.V. : Metall. Trans. A, 14A (1983), 1487-1495.

20) Flores, P., Tuninetti, V., Gilles, G., Gonry, P., Duchêne, L. \& Habrake, A.M. : J. Mater. Process. Technol., 210 (2010), 1772-1779.

21) An, Y.G., Vegter, H. \& Elliott, L. : J. Mater. Process. Technol., 155-156 (2004), 1616-1622.

22) Kuwabara, T. : J. Jpn. Soc. Technol. Plast., 57-669 (2016), 934-939. 